\title{
Two New Species of Euastacus (Decapoda: Parastacidae) from the Gondwana Rainforests of Central Eastern Australia
}

\author{
James M. Furse, ${ }^{1, *}{ }^{*}$ Kathrin L. Dawkins ${ }^{2}$ And Jason COUGHRan ${ }^{3}$ \\ ${ }^{1}$ Environmental Futures Centre, Griffith School of Environment, Gold Coast campus, Griffith University, \\ Queensland, 4222, Australia. \\ ${ }^{2}$ Australian Rivers Institute, Griffith School of Environment, Gold Coast campus, Griffith University, \\ Queensland, 4222, Australia. \\ ${ }^{3}$ Outback Ecology, 3/73 Troy Terrace, Jolimont, Western Australia, 6014, Australia. \\ *Corresponding Author.-j.furse@griffith.edu.au
}

\begin{abstract}
Two new species of the crayfish genus Euastacus are described from the Gondwana Rainforests on the Queensland - New South Wales border region of Australia, Euastacus binzayedi sp. n. and Euastacus angustus sp. n. These two small, poorly spinose species are broadly similar in appearance and colouration to Euastacus dalagarbe Coughran, from the same region. Both species can be readily distinguished from E. dalagarbe; Euastacus binzayedi $\mathrm{sp}$. n. by the numerous bumps and protrusions on the dorsal and ventral surfaces of its chelae, and Euastacus angustus sp. n. by its unusual, laterally compressed body shape, and the large ventromesial carpal spine. Cytochrome oxidase I divergence estimates from the most closely related species were high for both Euastacus binzayedi sp. $\mathrm{n}$. (4.8\%), and Euastacus angustus sp. n. (8.7\%). Morphologically, both of these new species belong in a clearly defined, poorly spinose grouping, and both appear to be exceptionally rare, each known from a single locality. [Keywords._Euastacus, Gondwana rainforests, New South Wales, Queensland, Parastacidae].
\end{abstract}

Submitted: 13 June 2012, Accepted: 27 October 2012, Published: 15 February 2013

\section{INTRODUCTION}

Euastacus is the most diverse genus in the family Parastacidae, and the largest of the ten Australian genera with 50 recognised species (McCormack and Coughran 2008; Coughran and Furse 2010; Coughran and McCormack 2011). In this paper we describe two additional species from the Gondwana Rainforests on the Queensland - New South Wales border (Figure 1).

One of the species described here, Euastacus binzayedi sp. n., was originally discovered when a single specimen was captured during a field expedition as part of an International Association of Astacology conference in 2006. A return expedition to the site in 2010 allowed the collection of additional specimens, enabling the formal description presented herein.

The other species, Euastacus angustus sp. n., is described from a single specimen, collected in 2002 as part of a $\mathrm{PhD}$ research project by one of the authors (JC). The unusual morphology of this specimen has been previously discussed (Coughran 2005, 2006), however despite repeated and numerous attempts, no further specimens have been located. Nevertheless, the specimen clearly represents a new species, with a distinctive and unique laterally compressed body, and in this paper we have applied analysis of the cytochrome oxidase subunit 1 (COI) gene fragment to confirm its species status.

\section{METHODS}

\section{Collection of Specimens}

Specimens of Euastacus binzayedi sp. n. were collected from Lamington National Park, Southeast Queensland on the $24^{\text {th }}$ of September 2010; specimens were located by turning rocks and were captured by hand or using a hand net. The single specimen of Euastacus angustus sp. n. was collected by hand from under a rock in a tributary of Brindle Creek, New South Wales on the $22^{\text {nd }}$ of October 2002. The coordinates of collection sites were recorded using a Global Positioning System. All specimens were preserved in $70 \%$ ethanol.

\section{Genetics}

Extraction, amplification and sequencing of DNA

Extractions of DNA were obtained from specimens using a variation of the $\mathrm{CTAB} /$ phenol-chloroform extraction protocol (Doyle and Doyle 1987). The mitochondrial cytochrome oxidase subunit 1 (i.e., COI) gene fragment was amplified using the primers CRCOI-F (5'-CWACMAAYCATAAAGAYATTGG-3') and CRCOI-R (5'-GCRGANGTRAARTARGCTCG-3') (Cook et al. 2008). All PCR reactions were performed on a GeneAmp PCR System 2700 and contained the following: $2.0 \mu \mathrm{L}$ DNA extract, 


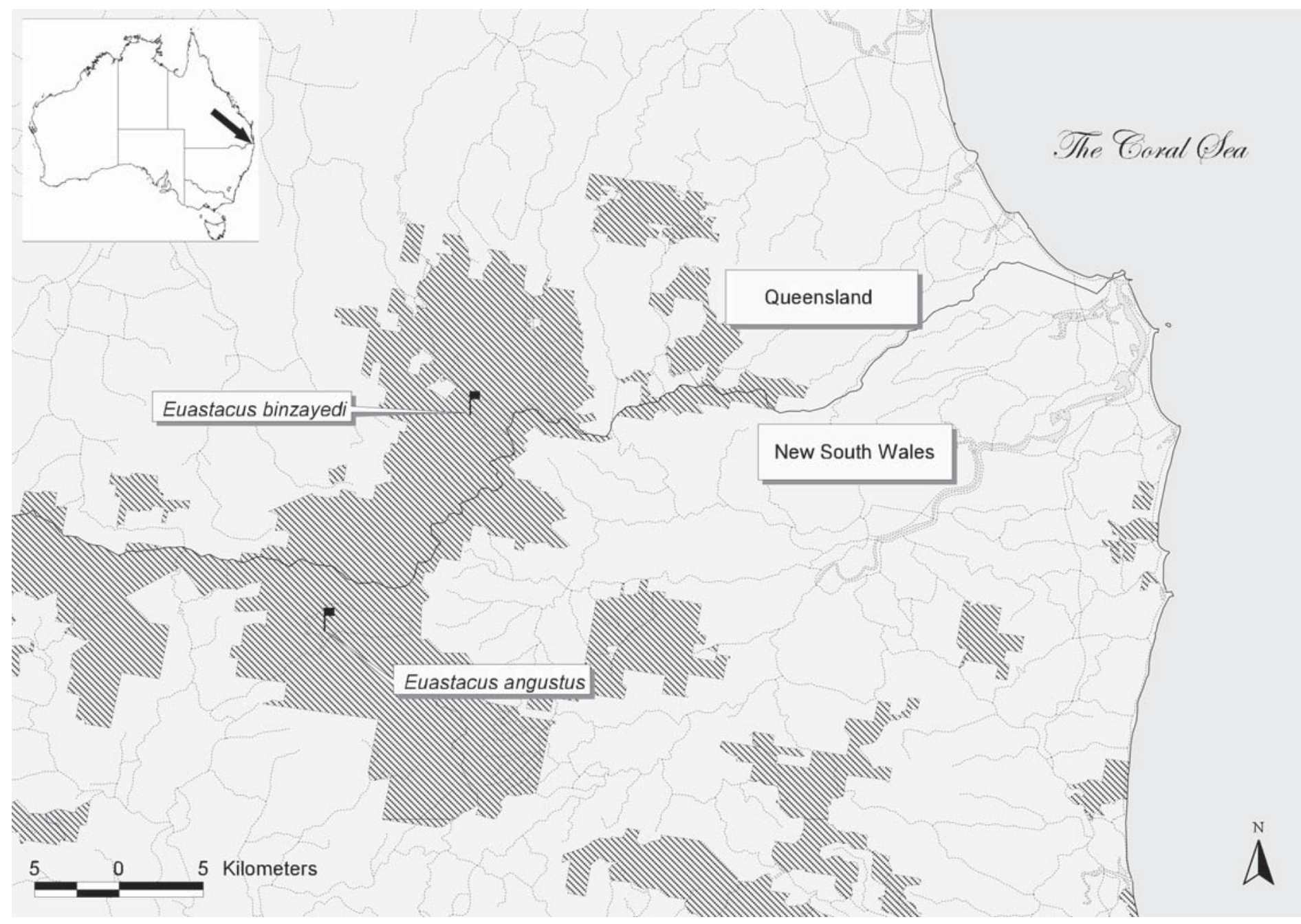

Figure 1. Map of the Gondwana Rainforests along the Queensland - New South Wales Border showing close proximity of type-localities for Euastacus binzayedi sp. n. and Euastacus angustus sp. n. Flags indicate the type localities, diagonal hatching indicates National Parks and other reserves, fine dashed lines indicate roads, the solid heavy line denotes the Qld-NSW Border. The numerous minor waterways in the region have been omitted for clarity.

$0.4 \mu \mathrm{L}$ forward primer $(10 \mathrm{mM}), 0.4 \mu \mathrm{L}$ reverse primer $(10 \mathrm{mM})$, $0.32 \mu \mathrm{L}$ dNTP $(10 \mathrm{mM}), 0.7 \mu \mathrm{L} \mathrm{MgCl}_{2}(50 \mathrm{mM}), 1.25 \mu \mathrm{L}$ buffer $(10 \times), 0.35 \mu \mathrm{L}$ Astral Red Taq (1U) and $7.08 \mu \mathrm{L} \mathrm{ddH}_{2} \mathrm{O}$. The amplification program consisted of the following conditions: $94^{\circ} \mathrm{C}$ for $5 \mathrm{~min}$; 40 cycles of: $30 \mathrm{sec}$ at $94^{\circ} \mathrm{C}, 1 \mathrm{~min}$ at $55^{\circ} \mathrm{C}, 30 \mathrm{sec}$ at $72^{\circ} \mathrm{C}$; then $7 \mathrm{~min}$ at $72^{\circ} \mathrm{C}$, with the reaction stored at $4^{\circ} \mathrm{C}$ until further analysis. The DNA was then purified using EXO SAP (Fermentas) on successfully amplified samples. Purification reactions contained $0.25 \mu \mathrm{L}$ Exonuclease I, 1.0 $\mu \mathrm{L}$ Shrimp Alkaline Phosphate and $5.0 \mu \mathrm{L}$ amplified PCR product, with the solution then incubated at $37^{\circ} \mathrm{C}$ for $35 \mathrm{~min}$, heated at $80^{\circ} \mathrm{C}$ for $20 \mathrm{~min}$, held at $15^{\circ} \mathrm{C}$, then stored at $4^{\circ} \mathrm{C}$ until further analysis. Further amplification reactions contained: $1.0 \mu \mathrm{L}$ purified PCR product, $5.5 \mu \mathrm{L}$ ddH $_{2} \mathrm{O}, 5.0 \mu \mathrm{L}$ Terminator Mix, $2.0 \mu \mathrm{L} 5 \times$ Terminator Mix Buffer and $1.0 \mu \mathrm{L}$ of the forward primer (CRCOI-F), and PCR reactions consisted of the following conditions: initial hold of $96^{\circ} \mathrm{C}$ for $1 \mathrm{~min} ; 30$ cycles of: $96^{\circ} \mathrm{C}$ for $10 \mathrm{sec}, 50^{\circ} \mathrm{C}$ for $5 \mathrm{sec}, 60^{\circ} \mathrm{C}$ for $4 \mathrm{~min}$; then a final hold at $4^{\circ} \mathrm{C}$. Samples were cleaned and then sequenced on an Applied Biosystems 3130 automated sequencing machine.

\section{Phylogenetic analysis}

One specimen from each type locality was sequenced for the COI gene fragment, and a specimen of Euastacus dalagarbe Coughran, was also sequenced (COI) as there was no existing COI sequence on record for this geographically proximal species. All available Euastacus COI sequences available on GenBank were obtained and aligned with the present sequences using Sequencher 4.1.2 (GeneCodes 2000). To allow informative comparisons between species, all sequences were cut to a length of 455 basepairs. A maximum likelihood tree was inferred using the program RAxML v7.0.0 (Stamatakis 2006) with 1000 bootstrap replicates (data not shown). Only those species shown in the phylogenetic tree to be most closely related to those in this study were retained (Appendix 1), with a maximum likelihood tree inferred from the reduced data set. Although bootstraps values were calculated, the relationships between species in this subset of Euastacus could not be accurately defined (i.e., low branch support values) and therefore the values are not shown. However, the same branching pattern between species were found across multiple trees. The mean net group sequence divergence estimates between species were 
calculated using MEGA5 (Tamura et al. 2011) and are presented as number of base substitutions with associated estimates of standard errors.

\section{Morphological Analysis}

Morphological examinations were performed with reference to earlier published taxonomic works on the genus (Riek 1951; Morgan 1986, 1988, 1997), and all measurements were made to the nearest $0.01 \mathrm{~mm}$ using digital vernier calipers. Measurements of regenerate chelae were not included in morphometric ratios. The standard dimension in this study was Occipital-Carapace Length (OCL, Morgan 1997), which describes the oblique distance from the posterior radius of the eye socket to the centre dorsal posterior of the carapace.

\section{SYSTEMATICS}

\section{Euastacus binzayedi, new species Coughran and Furse}

Figure 2

\section{Material Examined}

Holotype; male; $31.82 \mathrm{~mm}$ OCL; unnamed tributary/gully in Lamington National Park, southeast Queensland; $28^{\circ} \mathrm{S} 153^{\circ} \mathrm{E}$ (datum WGS84) precise coordinates available to bona fide researchers on request; elevation $\sim 900 \mathrm{~m}$ above sea level (a.s.1.); Jason Coughran, Kathryn L. Dawkins and James M. Furse; 24 September 2010; deposited in the Queensland Museum collection; Queensland Museum Registration Number QM 29175.

Paratypes; type locality; Jason Coughran, Kathryn L. Dawkins and James M. Furse; 4 females; 24 $4^{\text {th }}$ September 2010; deposited in the Queensland Museum collection; Queensland Museum Registration Number QM 29176.

\section{Diagnosis}

Male cuticle partition present. Ventro-lateral propodal spines absent. Thoracic spines absent. Abdominal spination barely discernible or absent; if present, lateral abdominal ( $\mathrm{Li}$ and $\mathrm{Lii}$ ) spines tiny and blunt; dorsal and dorso-lateral (D and DL) spines absent. 3 mesal carpal spines. Dorsal carpal spines absent. 2 rostral marginal spines. Numerous bumps and protrusions lateral to dactylar base, on both dorsal and ventral surfaces of propodus; extending posteriorly along propodus. 1 dorsal apical propodal spine. Numerous bumps and protrusions posterior to dactylar articulation, extending posteriorly to precarpal area of the propodus. Spines above propodal cutting edge absent (dorsally and ventrally). Spines above dorsal and ventral dactylar cutting edges generally absent. Usually 1 apical mesal dactylar spine. Other apical dactylar spines absent. Mesal dactylar basal spines absent. 0-1 dorsal mesal dactylar basal spines. Maximum Size: 32.23 mm OCL.

\section{Rostrum}

Rostrum extending apically to near or just beyond base of third antennal segment. Rostral carinae with slightly convergent to near parallel sides, slightly divergent at base. 2 rostral marginal spines per side, 1 apical spine followed by $2^{\text {nd }}$ spine beyond midlength; anterior-most spine larger; blunt. One female specimen with 3 marginal spines per side, posterior ones indistinct. Acumen spine similar in size to anterior-most marginal spine. OCL/Carapace Length: $0.85-87$. Rostral Width/OCL: $0.10-0.12$.

\section{Cephalon}

Numerous bumps on lateral surface of cephalon, with $2-4$ more pronounced; bumps blunt to moderate. Postorbital spine small to medium size, blunt to moderate; ridge reduced with a distinct longitudinal groove. Second postorbital spine absent, ridge present as a large, rounded boss. Basipodite spines absent. Coxopodite spine poorly developed. Interantennal spine medium to very elongate with slightly scalloped margins. Suborbital spine medium, and moderately pointed to sharp. Antennal squame reduced anteriorly, moderately inflated from $\sim 1 / 4$ length, or uniformly convex; marginal spines absent on antennal squame. Interantennal Scale Length/OCL: $0.11-0.14$.

\section{Thorax}

Cervical spines present in larger specimens as 2 rows of fine tubercles, in smaller specimens barely discernible as 2 faint rows of markings where tubercles are in larger specimens. Thoracic spines absent. A few general tubercles (4-5) are slightly more developed on specimens $>31.82 \mathrm{~mm}$ OCL, and could almost be considered as developing spines. General tubercles tiny to small, and of moderate to dense distribution. Areola with slight waisting at midlength in large specimen, parallel to slightly convergent in small and medium specimens. Areola Length/OCL: $0.23-0.28$. Total Areola Length/ OCL: $0.36-0.37$. Areola Width/OCL: $0.17-0.23$. Carapace Width/OCL: $0.49-0.52$. Carapace Depth/OCL: $0.49-0.51$.

\section{Abdomen}

Abdominal spination barely discernible or absent, $1-3$ tiny and blunt Li spines on somite 2, $1 \mathrm{Li}$ spine also on somites $3-6$ of one specimen. 1 tiny and blunt Lii spine occasionally present on somites $3-5$. DL and D spines absent. Abdominal boss absent. Abdomen Width/OCL: $0.47-0.55$. OCL/Total Length: 0.39-0.41.

\section{Tailfan}

Standard tailfan spines tiny or absent. Other marginal and surface spines absent on telson and uropods. Telson Length/OCL: $0.34-0.38$.

\section{Keel}

Pair 1 close to slightly apart and parallel. Pair 2 close and parallel to slightly closed. Pair 3 narrow, Pair 4 medium. Processes with setose posterior margins.

\section{Chelae}

Chelae elongate, particularly in single male specimen.

Merus. - 5-8 sharp dorsal meral spines, including one distomesal spine. Distolateral margin of merus with a sharp but very small spine.

Carpus. - 3 mesal carpal spines, $1^{\text {st }}$ offset ventrally. $1-2$ barely discernable lateral carpal spines. Ventral carpal spines large and sharp. 1 ventromesal carpal spine, smaller than ventral spine. Dorsal carpal spines absent. Dorsal carpal groove deep. 


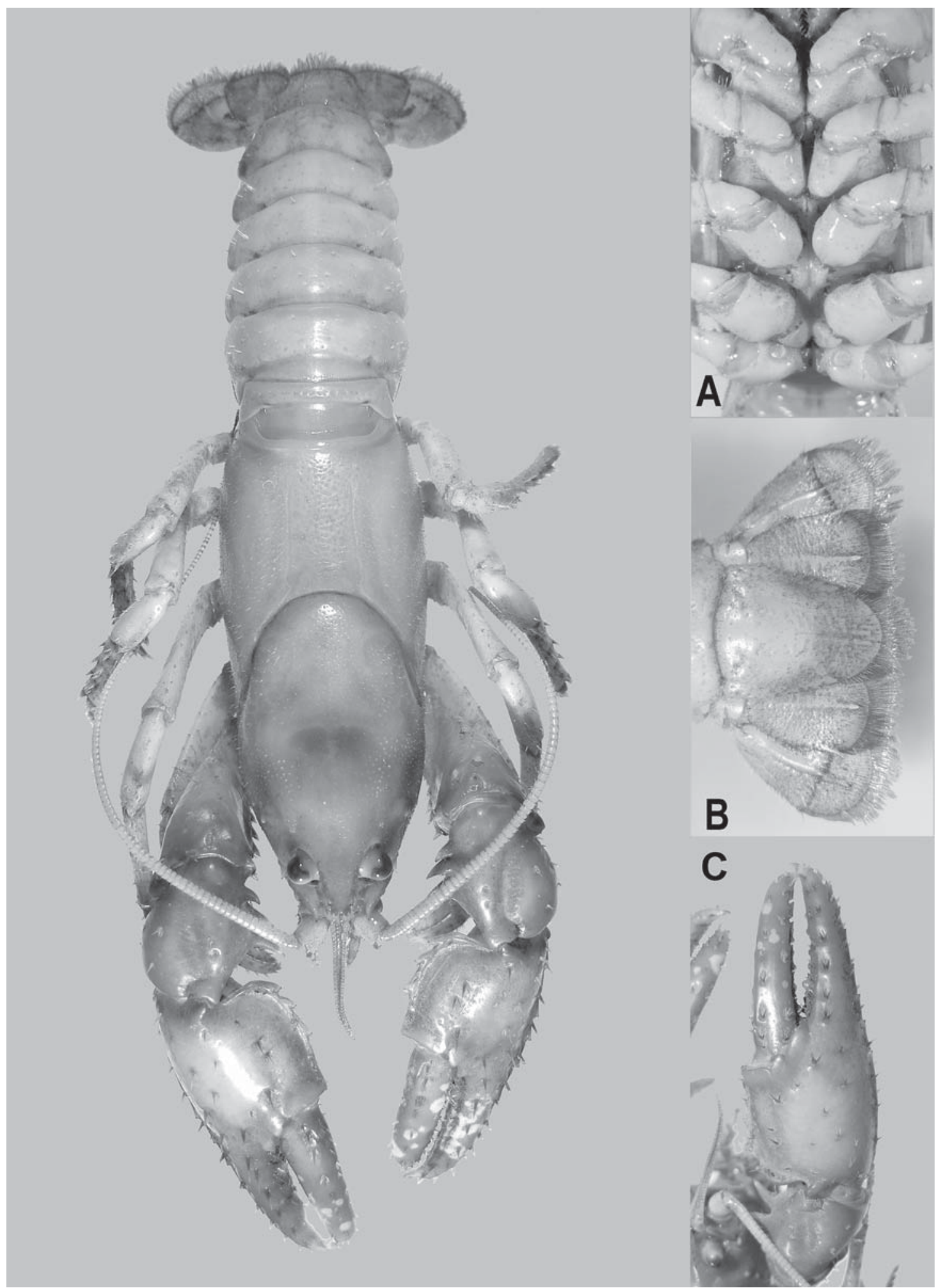

Figure 2. Euastacus binzayedi sp. n. Holotype, QM 29175. Insets: A) sternal keel; B) tailfan; C) chelae (OCL $31.82 \mathrm{~mm})$.

Propodus.- Dorso-lateral propodal spine row extending from apex to about $2 / 3$ propodal length, with 8 to 11 spines; additional spine occasionally present at base of propodus (row only extending to $1 / 2$ propodal length on one specimen; one regenerate chela with entire row present, 13 spines). Ventro-lateral propodal row absent. Mesal propodal spines numbering $4-6$. Numerous bumps and protrusions lateral to dactylar base, on both dorsal and ventral surfaces of propodus; protrusions extending posteriorly along propodus. 1 dorsal apical propodal spine ( 2 spines on a regenerate chela).

Two large, moderately developed bumps at dactylar articulation, distal bump developed into sharp spine on smallest specimens. Numerous bumps and protrusions posterior to dactylar 
articulation, extending posteriorly to the precarpal area of the propodus. Spines above propodal cutting edge absent (dorsally and ventrally). Propodal Width (PropW)/Propodal Length (PropL): $0.38-0.43$. Propodal Depth (PropD)/PropL: $0.25-0.29$.

Dactylus.- Spines above dorsal and ventral dactylar cutting edges generally absent (1 tiny apical spine on large male specimen, and 2 apical spines on a regenerate chela). 1 apical mesal dactylar spine (one specimen with 2 spines on one side). Other apical dactylar spines absent ( 1 spine on a regenerate chela). Mesal dactylar basal spines absent. Large male with 1 dorsal mesal dactylar basal spine; spine absent on other specimens. Distinct dactylar groove present. Dactylar Length (DactL)/PropL: $0.53-0.58$.

\section{Setation}

Moderate covering of setae on abdomen laterally, noticeably less dense on dorsal surface. Uniformly dense covering of setae on tailfan. Carapace with uniform covering of fine, single setae; distinct rows of setae tufts on rostrum margins, and posteriorly on postorbital grooves. Propodus and dactylus with very distinct and large tufts of setae, arranged in remarkably regular rows (reminiscent of fine tipped paintbrushes). Periopods with similar tufts of setae on distal-most segments.

\section{Punctation}

Uniform covering of very fine punctations on carapace; punctations slightly larger on abdomen. Chelae with deep punctations, associated with setae tufts.

\section{Colouration}

Euastacus binzayedi sp. n. is brown dorsally, with distinct dark brownish-red patches ventro-laterally. Distally, the second through fifth periopods are brown with bluish tinges on the tips of pairs 2 and 3, proximally all periopods are bright fluorescent orange. Dorsal surfaces of the chelae are mottled brownish green, tending to lighten to dark teal green distally. Proximally, the ventral surfaces of the chelae are bright fluorescent orange, and orange-brown with olive green mottling distally. Mesial carpal spines have light orange-brown tips.

\section{Sexes}

Male cuticle partition present.

\section{Etymology}

Named for His Royal Highness the Crown Prince Mohammed bin Zayed of the United Arab Emirates, in acknowledgement of his substantial contributions to conservation of endangered species, through the Mohamed bin Zayed Species Conservation Fund. The Fund supports conservation initiatives for plants and animals throughout the world, and has generously supported recent conservation initiatives for the highly imperiled crayfish genus Euastacus.

\section{Biological Notes}

This is a relatively small species of Euastacus. The four female specimens range from 18.56 to $32.23 \mathrm{~mm}$ OCL, the three smallest specimens $(18.56-27.34 \mathrm{~mm}$ OCL) have incised but calcified gonopores, without setation. The largest female's (32.23 $\mathrm{mm}$ OCL) gonopores are decalcified with heavy setation around the margins, indicating maturity. It would thus appear females become sexually mature at around $30 \mathrm{~mm}$ OCL.

The species is known only from the type locality, a small, well-shaded ephemeral gully with a dense subtropical rainforest canopy, at relatively high altitude $\sim 900 \mathrm{~m}$ a.s.l. (highest local peaks $\sim 1125 \mathrm{~m}$ a.s.l). Specimens were collected from around and under rocks; burrowing activity by crayfish was evident in the stream bed, but this could be attributable to the larger Euastacus sulcatus Riek, that also occurs at the site. One of the authors (JMF) has conducted surveys of E. sulcatus over the past 15 years in the area adjacent the type locality, however until recently only E. sulcatus has been captured. To date, surveys for additional sites harboring Euastacus binzayedi sp. n. have not been extensive (or successful), however surveys to clarify the distribution of Euastacus binzayedi sp. n. are ongoing.

The subtropical rainforest habitat of this species is within Lamington National Park, and is therefore protected by the Queensland Nature Conservation Act (1992). This habitat type is classified as Queensland Regional Ecosystem type 12.8.5 (complex Notophyll vine forest on Cainozoic igneous rocks), and has a Biodiversity Status of "No concern at present" throughout the State (DERM 2012). The type locality is within one of the 5 protected areas of this habitat type in Queensland, all of which are within a $100 \mathrm{~km}$ radius of the type locality.

\section{Euastacus angustus, new species Coughran and Dawkins} Figure 3

Euastacus sp. Coughran, 2005: pgs. 361, 373, Fig. 10A,B.

\section{Material Examined}

Holotype; male; $21.74 \mathrm{~mm}$ OCL; unnamed tributary, Border Ranges National Park, northeastern New South Wales; $28^{\circ} \mathrm{S}$ $153^{\circ} \mathrm{E}$ (datum WGS84), precise coordinates available to bona fide researchers on request; elevation 760 m a.s.l.; Jason Coughran; 1 October 2002; deposited in the Australian Museum collection; Australian Museum Registration Number P.89676.

\section{Diagnosis}

Body distinctly compressed laterally. Male cuticle partition present. Thoracic spines absent. 4 well developed and sharp rostral marginal spines per side, extending beyond midlength of rostrum. Basipodite spine large and sharp. Suborbital spine large and sharp. Abdomen without spines. Dorsal apical propodal spines absent. Ventro-lateral propodal spines absent. Mesal propodal spines numbering 3-4 with distinct gap between 1 and 2. Spines above propodal and dactylar cutting edges absent. 3 mesal carpal spines. Dorsal carpal spines absent. Ventromesal carpal spine as large or larger than ventral spine. 1 very small apical mesal dactylar spine; other apical and dactylar basal spines absent. Maximum Size: $21.74 \mathrm{~mm}$ OCL.

\section{Rostrum}

Rostrum extending apically to near base of third antennal segment, narrow and triangular, diverging at base. 4 well 


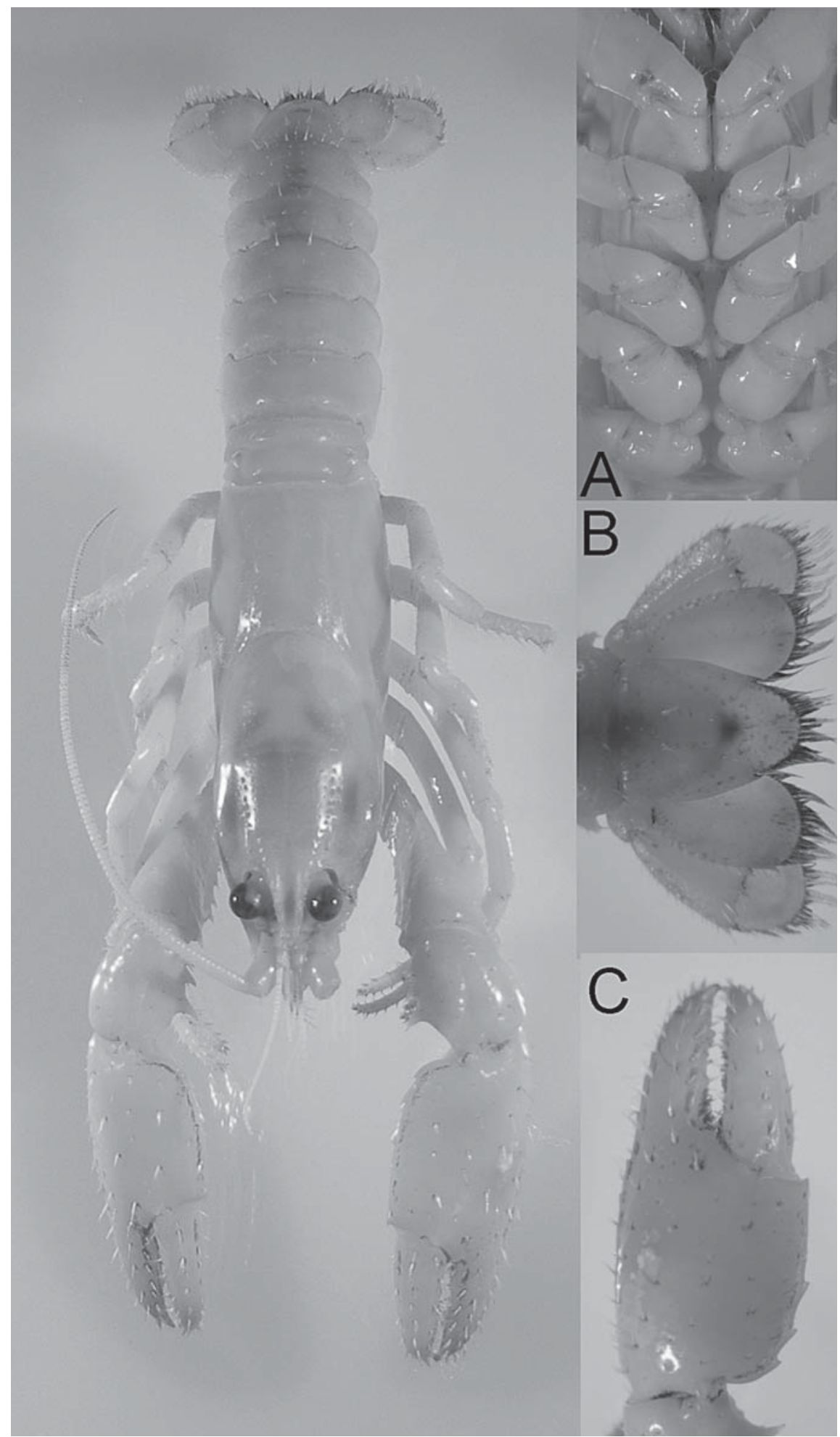

Figure 3. Euastacus angustus sp. n. Holotype, AM P.89676. Insets: A) sternal keel; B) tailfan; C) chelae (OCL $21.74 \mathrm{~mm}$ ).

developed and sharp rostral marginal spines per side, extending beyond midlength of rostrum to near base of orbit; size of spines decreases slightly anteriorly. Acumen larger than rostral marginal spines. OCL/Carapace Length: 0.87. Rostral Width/OCL: 0.77.

\section{Cephalon}

Cephalon laterally smooth apart from a few very small, blunt spines. Medium and sharp $1^{\text {st }}$ postorbital spine; moderately developed postorbital ridge. Second postorbital spine very small. Basipodite spine large and sharp. Coxopodite spine poorly developed, small and blunt. Interantennal spine elongate with smooth margins. Suborbital spine large and sharp. Antennal squame inflated at midlength, relatively narrow but distinctly triangular in profile; marginal spines absent. Interantennal Scale Length/OCL: 0.13 . 


\section{Thorax}

Cervical spines barely discernible. Thoracic spines absent. General tubercles finely punctate. Areola fuses with branchiocardiac groove with a second, subsidiary dorso-lateral groove immediately posterior to junction. Areola tapers posteriorly, with two rows of distinctive, large and deep punctations mesial to areola grooves. Areola Length/OCL: 0.29. Total Areola Length/OCL: 0.40. Areola Width/OCL: 0.18. Carapace Width/OCL: 0.47. Carapace Depth/ OCL: 0.53 .

\section{Abdomen}

Li, Lii, DL and D spines absent. Abdominal boss absent. Abdomen Width/OCL: 0.43. OCL/Total Length: 0.41.

\section{Tailfan}

Standard tailfan spines medium and sharp. Telsonic surface and marginal spines absent, uropodal surface spines absent. Telson Length/OCL: 0.34 .

\section{Keel}

Pair 1 reduced; close and parallel. Pair 2 slightly apart and open. Pair 3 narrow and 4 medium. All processes thin, and with setose posterior margins.

\section{Chelae}

Chelae of intermediate shape (Morgan 1997).

Merus. $-6-8$ dorsal meral spines; distomeral spine absent, distolateral spine small.

Carpus. - 3 mesal carpal spines, $1^{\text {st }}$ very slightly offset ventrally. 1 barely discernible lateral carpal spine (at distal edge). Ventral carpal spines medium and sharp. 1 ventromesal carpal spine, medium to large and sharp (as large or larger than ventral spine). Dorsal carpal spines absent. Dorsal carpal groove deep.

Propodus.- Dorso-lateral propodal spine row extends to about $2 / 3$ to $3 / 4$ of propodal length. Ventro-lateral propodal row absent. Mesal propodal spines numbering $3-4$, with a distinct gap between first and second. Dorsal spines lateral to dactylar base absent. 1 barely discernible ventral spine lateral to dactylar base, on right cheliped only. Dorsal apical propodal spines absent. 2 small blunt bumps at dactylar articulation. Spines posterior to dactylar articulation absent. Precarpal spines absent. Dorsal and ventral spines above propodal cutting edge absent. PropW/PropL: 0.39. PropD/PropL: 0.26. PropL/OCL: 0.96 .

Dactylus.- Spines above dactylar cutting edge absent (dorsal and ventral). 1 very small apical mesal dactylar spine. Other apical and dactylar basal spines absent. Distinct $2^{\text {nd }}$ dactylar groove along mesal edge. DactL/PropL: 0.49.

\section{Setation}

Setation sparse on abdomen (a few very small setal tufts mainly on flanks), uniform covering of setal tufts on tailfan, very sparse setation of single setae on carapace, 2 very distinct and large setal tufts immediately posterior to cardio-areola groove. The two distal segments of periopods are quite heavily setose; propodus and dactylus also quite heavily setose, with regular and large setal tufts, increasing distally.

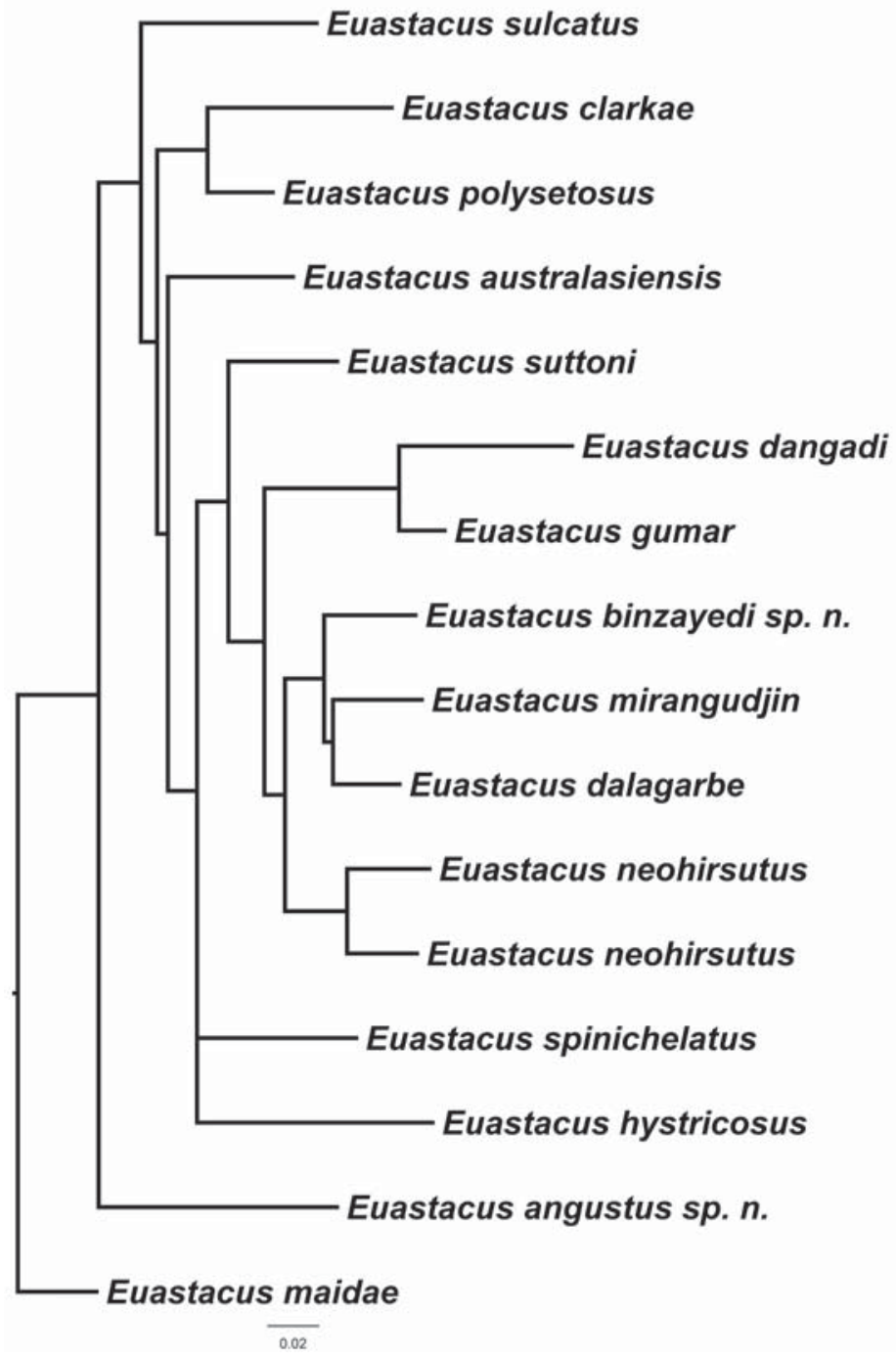

Figure 4. Maximum likelihood phylogram based on COI sequences showing relationship between Euastacus species.

\section{Punctation}

Abdomen and carapace with a uniform but microscopic covering of punctations, chelae with a distinct but irregular covering of punctations, some quite deep.

\section{Colouration}

The holotype has retained little colour after several years in ethanol. When originally collected, general body colouration was noted as light olive-brown to orange-brown dorsally, and cream ventrally; chelae dorsally orange, with darker orange or orangered markings at articulations (i.e., between merus/carpus, carpus/ propodus and propodus/dactylus); ventrally, chelae a paler yelloworange, with orange markings at articulations; fingers washed bluish-green.

\section{Sexes}

The only specimen, a male, has a cuticle partition.

\section{Etymology}

Derived from the Latin word angustus (meaning narrow, close, contracted), to reflect the laterally compressed body of the species, an unusual condition for the genus Euastacus. 
割

ถ

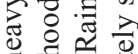

宩

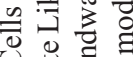

i :

ब킬

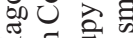

司

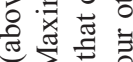

o 0

op

क्ष

क्ष क्षे के

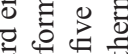

踏

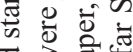

उ

要

旅 踏

范

สิ के

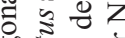

क्ष

3 है

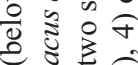

卷

这

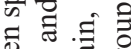

的䒕

के 0

교 요

एँ़े त्रे के के

ट $\equiv \overline{0}$

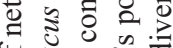

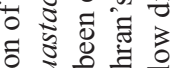

을 눤을

웡

की

ह 0

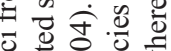

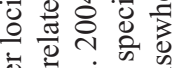

可宁元

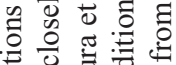

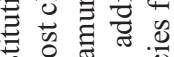

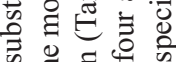

के है के

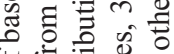

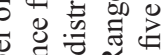

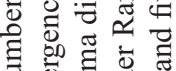

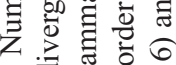

․

융 웜

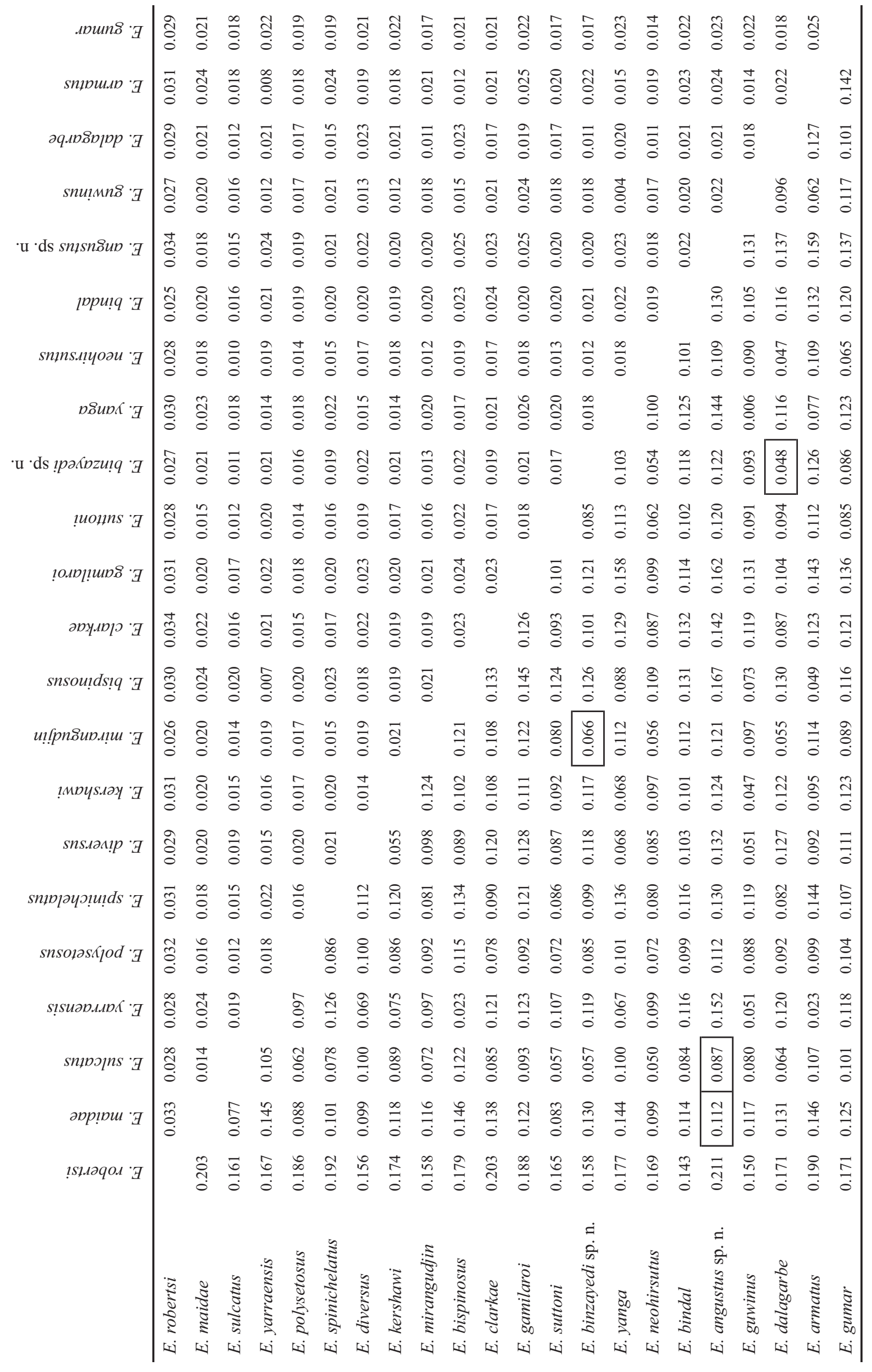


Table 2. Species of Euastacus that occur in Gondwana rainforest areas along the Queensland - NSW border (within $50 \mathrm{~km}$ of the border). Coughran's Group from Coughran (2008), Extent of Occurrence (EOO) from Furse and Coughran (2011) and calculated as per IUCN Red List Guidelines (IUCN 2011). Number of sites from author's unpublished data (including Coughran 2006; Furse 2010) and various other published accounts (including Riek 1956; Morgan 1988; Coughran 2007; Coughran and Leckie 2007; McCormack et al. 2010; Coughran 2011a, b; Furse et al. 2012).

\begin{tabular}{llllcc}
\hline Species & Authority & State & $\begin{array}{l}\text { Coughran's } \\
\text { Group }\end{array}$ & $\begin{array}{c}\text { EOO } \\
\left(\mathrm{km}^{2}\right)\end{array}$ & $\begin{array}{c}\text { Number of } \\
\text { Sites }\end{array}$ \\
\hline E. angustus sp. n. & Coughran and Dawkins & NSW & Poorly spinose & - & 1 \\
E. binzayedi sp. n & Coughran and Furse & Qld & Poorly spinose & - & 1 \\
E. dalagarbe & Coughran & NSW & Poorly spinose & $\sim 48.5$ & 8 \\
E. girurmulayn & Coughran & NSW & Poorly spinose & $\sim 6.5$ & 3 \\
E. gumar & Morgan & NSW & Spinose & $\sim 985$ & 12 \\
E. guruhgi & Coughran & NSW & Poorly spinose & $\sim 7.5$ & 4 \\
E. jagabar & Coughran & NSW & Poorly spinose & $\sim 2.5$ & 4 \\
E. jagara & Morgan & Qld & Poorly spinose & $\sim 21.5$ & 9 \\
E. maidae & Riek & Qld & Poorly spinose & $<10$ & 1 \\
E. mirangudjin & Coughran & NSW & Poorly spinose & $\sim 42.5$ & 5 \\
E. pilosus & Coughran and Leckie & NSW & Spinose & $\sim 1000$ & 11 \\
E. sulcatus & Riek & Qld-NSW & Spinose & $\sim 8,000$ & $>40$ \\
E. suttoni & Clark & Qld-NSW & Spinose & 20,000 & $>30$ \\
E. valentulus & Morgan & Qld-NSW & Spinose & 20,000 & $>30$ \\
\hline
\end{tabular}

\section{Biological Notes}

Euastacus angustus sp. n. is known only from the type locality, and despite extensive efforts over a number of years, additional specimens could not be located. This appears to be an exceptionally rare species, and its biology is unknown. Two other species, E. dalagarbe and E. sulcatus, also occur at the type locality.

The type locality is a small, well-shaded stream with a dense subtropical rainforest canopy, at reasonably high altitude $\sim 760 \mathrm{~m}$ a.s.l. The type locality is within The Border Ranges National Park (in New South Wales) and is thus protected by the New South Wales National Parks and Wildlife Act (1974). The Border Ranges National Park abuts Queensland's Lamington National Park, and both parks feature the same geology and unbroken stand of subtropical rainforest (as indicated in Figure 1).

These similarities have resulted in the easterly section of the Qld-NSW border region (including the type locality in NSW) being classified as within the Southeast Queensland Bioregion. As previously outlined for Euastacus binzayedi sp. n., the habitat occupied by Euastacus angustus sp. n. is complex Notophyll vine forest on Cainozoic igneous rocks, Queensland Regional Ecosystem type 12.8.5 (DERM 2012).

\section{DISCUSSION}

\section{Results of Genetic Analyses}

The divergence estimates between the species in this study and their most closely related species based on the tree presented (Figure 4) were high (Euastacus binzayedi sp. n. and E. dalagarbe (0.048 \pm 0.011 Standard Error (SE)); Euastacus binzayedi sp. n. and Euastacus mirangudjin Coughran (0.066 $\pm 0.013 \mathrm{SE})$; Euastacus angustus sp. n. and Euastacus maidae Riek (0.112 \pm 0.018 SE); Euastacus angustus sp. n. and E. sulcatus $(0.087 \pm 0.015 \mathrm{SE})$ ). Divergence estimates between other recognised species in the genus are as low as $0.006 \pm 0.004$ SE (i.e., between Euastacus guwinus Morgan, and Euastacus yanga Morgan), therefore the COI results in this study are consistent with the recognition of two new species (Table 1).

The type localities of these two new species are within 20 $\mathrm{km}$ of each other in the Gondwana Rainforests of Central Eastern Australia, which contain the World's largest remaining reserve of subtropical rainforest. The highland area along the Queensland - New South Wales border is a distinct hotspot of Euastacus diversity, with 12 further species known to occur within $50 \mathrm{~km}$ of the border (Table 2).

The vast majority of these species have highly restricted ranges and are only known to occur in a handful of locations. This hotspot of Euastacus diversity occurs within one of the largest remaining contiguous area of montane subtropical rainforest, however there are large areas of suitable habitat within this region that have yet to be surveyed, particularly in Queensland (Furse 2010; Furse and Coughran 2011; Coughran and Furse 2012). Given the rugged, mountainous terrain, and the fact that these species may occur in only a single gully, there is considerable potential for discovery of additional new species.

\section{ACKNOWLEDGMENTS}

We thank the Mohamed bin Zayed Species Conservation Fund (Abu Dhabi, the United Arab Emirates), for their recent support of our conservation research on the genus Euastacus. We appreciate our two anonymous reviewers for providing useful comments on an 
earlier version of this paper. This research project was supported by the Environmental Futures Centre, the Australian Rivers Institute, and the Griffith School of Environment, Griffith University, Gold Coast campus, Queensland, Australia. Research in Queensland and New South Wales National Parks was conducted under Queensland DERM Scientific Purposes Permit WITK08599510, and New South Wales Department of Primary Industries and Fisheries Permit P00/025, both issued to Jason Coughran.

\section{LITERATURE CITED}

Cook BD, Pringle CM AND Hughes JM (2008). Molecular evidence for sequential colonization and taxon cycling in freshwater decapod shrimps on a Caribbean island. Molecular Ecology 17(4):1066-1075.

Coughran J (2005). New crayfishes (Decapoda: Parastacidae: Euastacus) from northeastern New South Wales, Australia. Records of the Australian Museum 57(3):361-374.

Coughran J (2006). Biology of the freshwater crayfishes of Northeastern New South Wales, Australia. PhD Thesis. School of Environmental Science and Management. Southern Cross University, Lismore, New South Wales, Australia.

Coughran J (2007). Distribution, habitat and conservation status of the freshwater crayfishes, Euastacus dalagarbe, E. girurmulayn, E. guruhgi, E. jagabar and E. mirangudjin. Australian Zoologist 34(2):222-227.

Coughran J (2008). Distinct groups in the genus Euastacus? Freshwater Crayfish 16:125-132.

Coughran J (2011a). Aspects of the biology and ecology of the Orange-Bellied Crayfish, Euastacus mirangudjin Coughran 2002, from northeastern New South Wales. Australian Zoologist 35(3):750-756.

Coughran J (2011b). Biology of the Blood Crayfish, Euastacus gumar Morgan 1997, a small freshwater crayfish from the Richmond Range, northeastern New South Wales. Australian Zoologist 35(3):685-697.

Coughran J And Furse JM (2010). An assessment of genus Euastacus (49 species) versus IUCN Red List criteria. Report prepared for the global species conservation assessment of crayfishes for the IUCN Red List of Threatened Species. Pp. 170. The International Association of Astacology, Auburn, Alabama, USA.

Coughran J And Furse JM (2012). Conservation of freshwater crayfish in Australia. Crustacean Research, Special Number $7: 25-34$.

Coughran J And Leckie S (2007). Euastacus pilosus n. sp., a new crayfish from the highland forests of northern New South Wales, Australia. Fishes of Sahul 21(1):309-316.

Coughran J And McCormack RB (2011). Euastacus morgani sp. n., a new spiny crayfish (Crustacea, Decapoda, Parastacidae) from the highland rainforests of eastern New South Wales, Australia. Zookeys 85:17-26.

DERM (2012). Regional ecosystem details for 12.8.5 Queensland Government, Department of Environment and Resource Management, Brisbane, Queensland, Australia.
Doyle JJ AND Doyle JL (1987). A rapid DNA isolation procedure for small quantities of leaf tissue. Phytochemistry Bulletin 19(1):11-15.

FURSE JM (2010). Ecosystem engineering by Euastacus sulcatus (Decapoda: Parastacidae) in the Hinterland of the Gold Coast, Queensland, Australia. PhD Thesis. Griffith School of Environment. Griffith University, Gold Coast, Queensland, Australia.

Furse JM AND Coughran J (2011). An assessment of the distribution, biology, threatening processes and conservation status of the freshwater crayfish, genus Euastacus (Decapoda: Parastacidae), in Continental Australia. I. Biological Background and Current Status. Crustaceana Monographs 15 (Special edition: New Frontiers in Crustacean Biology):241-252.

Furse JM, Coughran J AND WiLd CH (2012). Report of a mass mortality of Euastacus valentulus (Decapoda: Parastacidae) in southeast Queensland, Australia, with a discussion of the potential impacts of climate change induced severe weather events on freshwater crayfish species. Crustacean Research: Special Number 7:15-24.

GeneCodes (2000). Sequencher (Version 4.1.2). Gene Codes Corporation, Ann Arbor, Michigan, USA.

IUCN (2011). Guidelines for using the IUCN red list categories and criteria. Version 9.0 (September 2011). Prepared by the Standards and Petitions Subcommittee of the IUCN Species Survival Commission. 87 pages.

McCormack RB AND Coughran J (2008). Euastacus maccai, a new freshwater crayfish from New South Wales. Fishes of Sahul 22(4):471-476.

McCormack RB, Coughran J, Furse JM and Van-Der-Werf P (2010). Conservation of imperiled crayfish - Euastacus jagara (Decapoda: Parastacidae), a highland crayfish from the Main Range, South-Eastern Queensland, Australia. Journal of Crustacean Biology 30(3):531-535.

Morgan GJ (1986). Freshwater crayfish of the genus Euastacus Clark (Decapoda, Parastacidae) from Victoria. Memoirs of the Museum of Victoria 47(1):1-57.

Morgan GJ (1988). Freshwater crayfish of the Genus Euastacus Clark (Decapoda: Parastacidae) from Queensland. Memoirs of The Museum of Victoria 49(1):1-49.

Morgan GJ (1997). Freshwater crayfish of the genus Euastacus Clark (Decapoda: Parastacidae) from New South Wales, with a key to all species of the genus. Records of the Australian Museum, Supplement 23:110.

RIEK EF (1951). The freshwater crayfish (family Parastacidae) of Queensland, with an appendix describing other Australian species. Records of the Australian Museum 22:368-388.

RIEK EF (1956). Additions to the Australian freshwater crayfish. Records of the Australian Museum 24:1-6.

Stamatakis A (2006). RAxML-VI-HPC: Maximum likelihoodbased phylogenetic analyses with thousands of taxa and mixed models. Bioinformatics 22(21):2688-2690. 
Tamura K, Nei M and Kumar S (2004). Prospects for inferring very large phylogenies by using the neighbor-joining method. Proceedings of the National Academy of Sciences (USA) 101(30):11030-11035.

Tamura K, Peterson D, Peterson N, Stecher G, Nei M and KUMAR S (2011). MEGA5: Molecular Evolutionary Genetics Analysis using Maximum Likelihood, Evolutionary Distance, and Maximum Parsimony Methods. Molecular Biology and Evolution 28(10):2731-2739.

Appendix 1. Genbank accession numbers for species examined in this study.

\begin{tabular}{lc}
\hline Species & $\begin{array}{c}\text { GenBank } \\
\text { Accession } \\
\text { Number }\end{array}$ \\
\hline E. sulcatus & DQ006391.1 \\
E. maidae & DQ006354.1 \\
E. polysetosus & DQ006363.1 \\
E. australasiensis & DQ006301.1 \\
E. hystricosus & DQ006346.1 \\
E. spinichelatus & DQ006383.1 \\
E. clarkae & DQ006321.1 \\
E. gumar & DQ006340.1 \\
E. dangadi & DQ006328.1 \\
E. neohirsutus & DQ006358.1 \\
E. mirangudjin & DQ006361.1 \\
E. suttoni & DQ006355.1 \\
\hline
\end{tabular}


